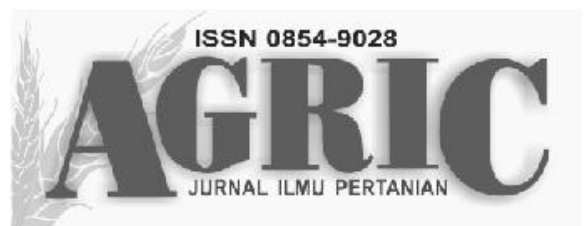

Fakultas Pertanian dan Bisnis Universitas Kristen Satya Wacana Jl. Diponegoro 52-60 SALATIGA 50711 - Telp. 0298-321212 ext 354 email: agric_fpb@yahoo.co.id, website: ejournal.uksw.edu/agric

\title{
PEMBAGIAN KERJA SECARA GENDER DALAM PEMBERDAYAAN PANGAN LOKAL (STUDI KASUS DI DESA MOROREJO KECAMATAN TEMPEL KABUPATEN SLEMAN)
}

\author{
GENDER DIVISION OF HOUSEHOLD LABOR \\ IN LOCAL FOOD EMPOWERMENT \\ (CASE STUDY IN MOROREJO VILLAGE TEMPEL SUB-DISTRICT \\ SLEMAN REGENCY)
}

\author{
Mesalia Kriska \\ Sekolah Pascasarjana, Universitas Gadjah Mada Yogyakarta \\ mesalia_kriska@yahoo.co.id
}

Diterima 18 Mei 2016, disetujui 11 Juli 2016

\begin{abstract}
This research aims to know about gender division of household labor in the empowerment of local food in Tempel Sub-District, Sleman Regency. Research method that is used was qualitative methods with case study approach. This research held in Mororejo Village, Tempel Sub-District. This location selected purposively because that village is the only one village which has the group of local food empowerment. Data gathered by participatory observation, interview, and documentation. The results showed that women dominated in every empower activity, that is training of local food processing, arisan, local food contests, and making the product at home. Man in household only involved in a hard work that need more power, like harvesting the cassava as a main ingredient and support activity for his wife, that is accompany his wife to go shopping at traditional market. In this case, there was gender relations in the empowerment activity of local food.
\end{abstract}

Keywords: gender division, local food empowerment 


\section{PENDAHULUAN}

Undang-Undang Nomor 18 tahun 2012 tentang Pangan menyebutkan bahwa pangan lokal adalah makanan yang dikonsumsi oleh masyarakat setempat sesuai dengan potensi dan kearifan lokal di suatu daerah. Peraturan tersebut muncul akibat fenomena penggantian makanan pokok ke beras pada Revolusi Hijau menjadikan potensi pangan lokal sedikit demi sedikit mulai pudar, dan pada akhirnya seiring berjalannya waktu, terjadi kerawanan pangan di beberapa rumah tangga.Kondisi tersebut menuntut pemerintah kembali menggalakkan konsumsi pangan lokal kepada masyarakat demi menjamin tercapainya ketahanan pangan di tingkat keluarga. Penggalakan tersebut dilakukan pemerintah dengan menjalankan berbagai program, seperti kegiatan pemberdayaan berupa pelatihan ragam olahan pangan lokal, lomba olahan pangan lokal, dan sebagainya.

Kegiatan pemberdayaan pangan lokal dilakukan dalam sebuah kelompok, yang umumnya beranggotakan ibu-ibu, dan dilakukan dalam partai kecil untuk variasi konsumsi individu, hingga dilakukan dalam partai besar sebagai tambahan pendapatan keluarga. Nugroho (2008) mengartikan pemberdayaan perempuan dilakukan salah satunya untuk meningkatkan kemampuan untuk melibatkan diri dalam program pembangunan sebagai partisipan aktif (subjek), dengan terlibat dalam setiap program, baik dalam melakukan perencanaan, pelaksanaan, monitoring, dan evaluasi, serta meningkatkan kemampuan dalam mengelola usaha untuk menunjang peningkatan kebutuhan rumah tangga.

Dengan demikian, dalam kegiatan pemberdayaan pangan lokal tersebut wanita diberdayakan untuk dilibatkan dalam kegiatan pembangunan dengan proses pemberdayaan terlebih dahulu, yang merupakan implementasi dari Gender and Development (GAD). Mosse (2007) mengung- kapkan GAD merupakan satu-satunya pendekatan terhadap wanita dalam pembangunan yang melihat semua aspek kehidupan wanita dan semua kerja yang dilakukan wanita, baik kerja produktif, reproduktif, privat, maupun publik, dan menolak upaya apapun untuk menilai rendah pekerjaan mempertahankan keluarga dan rumah tangga. GAD di Indonesia merupakan perwujudan dari gender mainstreaming yang harapannya agar kebijakan pemerintah saat ini memperhitungkan terjadinya kesetaraan gender.

Istilah "gender" dikemukakan oleh para ahli sosial dengan maksud menjelaskan perbedaan antara pria dan wanita terkait dengan peran, fungsi, dan tanggung jawab yang merupakan hasil dari sifat bawaan yang diciptakan oleh Tuhan dan konstruksi sosial yang terus berubah seiring dengan perkembangan jaman. Awal mula kemunculannya adalah karena proses pengintegrasian wanita dalam kegiatan pembangunan yang melabelkan wanita dalam stereotipe tertentu sehingga akan mengancam terjadinya subordinasi, kekerasan pada wanita, marjinalisasi pekerjaan, dan yang paling sering terjadi pada wanita di rumah tangga, yaitu double burden atau beban kerja ganda. Beban kerja ganda pada wanita telah nyata terjadi di masyarakat, dan dimulai sejak seorang wanita memutuskan untuk berumahtangga, karena mereka melakukan banyak peran sekaligus (multiple role), seperti melayani pria (marital role), mengurus anak (parental role), manajer rumah tangga (household role), bekerja di luar rumah, dan sebagai anggota masyarakat (social role) (Schiller, 1978). Beban kerja yang berlipat tersebut harus menjadi perhatian bagi pemerintah yang akan menjadikan mereka subjek pembangunan, karena terkait dengan keterlibatan mereka dalam rangkaian kegiatan pembangunan.

Langkah awal kegiatan pemberdayaan di Indonesia dimulai dengan melakukan pengintegrasian perempuan dalam setiap sektor di 
publik, dan pada akhirnya, menjadikan perempuan sebagai subjek pembangunan dengan menjadikan mereka pelaku akan sebuah program. Kesetaraan beban kerja juga merupakan tujuan akhir dari program-program yang diberlakukan oleh pemerintah, sehingga prinsip pembagian kerja berbasis gender dalam program pemerintah yang mengkaitkan kegiatan perempuan dalam rumah tangga pun dapat terlaksana dengan baik.

Kegiatan pemberdayaan pangan lokal di Kabupaten Sleman merupakan implementasi dari kebijakan pemerintah dalam rangka mencapai ketahanan pangan dan pengentasan rawan pangan dan gizi di tingkat daerah.Salah satunya yaitu di Kecamatan Tempel, yang menunjukkan warna kuning (waspada) pada peta rawan pangan dan gizi DIY tahun 2013.Di sisi lain, masyarakat di Kecamatan Tempel mendukung secara penuh kegiatan pemberdayaan pangan lokal tersebut dengan membentuk sebuah kelompok, dan terus mengadakan pelatihan serta penelusuran potensi lokal yang bisa diolah dan dijadikan sumber pangan selain beras, seperti ketela pohon, ketela rambat, jagung, dan tanaman daun-daunan yang ada di lingkungan sekitar (daun kemangi, kenikir, seledri, dan tapak liman). Kegiatan tersebut diharapkan dapat memberikan keuntungan ganda bagi masyarakat sekitar, selain memberikan sajian beragam bagi keluarganya, juga mampu memberikan pendapatan bagi rumah tangga dengan memproduksi olahan pangan lokal tersebut dalam jumlah yang besar dan memasarkannya.

Oleh karena itu, jika pemerintah ingin mencapai program yang berbasis gender, pemerintah harus memperhatikan aktivitas pesertanya secara keseluruhan dan juga mempertimbangkan keterlibatan laki-laki dan perempuan secara seimbang dalam program tersebut. Dengan demikian penelitian ini dilakukan untuk mengetahui pembagian kerja secara gender dalam kegiatan pemberdayaan pangan lokal di Desa Mororejo.

\section{METODE PENELITIAN}

Metode dasar yang digunakan oleh peneliti adalah metode penelitian kualitatif. Ada berbagai macam strategi yang dapat digunakan dalam penelitian kualitatif, dan dalam penelitian ini menggunakan strategi studi kasus. Creswell (2014) mengemukakan studi kasus merupakan pendekatan kualitatif dengan cara mengumpulkan data dari berbagai sumber informasi dengan mengeksplorasi kehidupan nyata, sistem terbatas oleh sebuah kasus, dalam hal ini yaitu kegiatan pemberdayaan pangan lokal di Kecamatan Tempel Kabupaten Sleman.

Penelitian dilaksanakan di Desa Mororejo yang merupakan satu-satunya desa di Kecamatan Tempel yang aktif melaksanakan kegiatan pemberdayaan pangan lokal dalam sebuah kelompok yang anggotanya terdiri dari ibu rumah tangga.Informan kunci dalam penelitian ini yaitu peserta kegiatan pemberdayaan pangan lokal di Desa Mororejo Kecamatan Tempel Kabupaten Sleman, yang terdiri dari ketua, sekretaris, dan 4 orang anggota aktif.

\section{Profil Peserta Kegiatan Pemberdayaan Pangan Lokal Desa Mororejo}

Kelompok pemberdayaan pangan lokal di Desa Mororejo berdiri pada tahun 2014, seiring dengan penetapan Desa Mororejo dalam Program Desa Mandiri Pangan (Demapan). Program tersebut dilakukan karena desa ini menunjukkan warna kuning pada peta rawan pangan dan gizi di tahun 2013, yang berarti bahwa desa ini masuk dalam kategori rawan pangan sehingga pemerintah melakukan upaya untuk peningkatan ketahanan pangan melalui program Demapan. Desa yang memperoleh program ini dapat menjadi desa yang masyarakatnya mempunyai kemampuan untuk mewujudkan ketahanan pangan dan gizi sehingga dapat menjalani hidup sehat dan produktif dari hari ke hari, melalui pengembangan sistem ketahanan pangan yang meliputi: subsistem 
ketersediaan, subsistem distribusi, dan subsistem konsumsi dengan memanfaatkan sumberdaya setempat secara berkelanjutan. Namun demikian seiring berjalannya waktu, kelompok yang awal mula didirikan hanya sebagai bentuk pelaksanaan program Demapan yang mendukung keberadaan pangan lokal, kini sudah mulai berkembang dan dikenal sebagai 'kelompok pangan lokal' di lingkup Kecamatan Tempel.

Kelompok Pemberdayaan Pangan Lokal di Desa Mororejo diikuti oleh 26 anggota yang merupakan perwakilan dari 13 dusun, yaitu Dusun Jetis, Rebobong Lor, Rebobong Kidul, Plumbon Cilik, Plumbon Kidul, Plumbon Tengah, Plumbon Lor, Karanggawang Kulon, Karanggawang Wetan, Kragan, Duren Sawit, Kaliasin, dan Dusun Domban. Dari masing-masing dusun tersebut terdapat 2 orang perwakilan yang aktif mengikuti kegiatan kelompok, yang nantinya diharapkan dapat menjadi kader dan dapat mengajarkan pada masyarakat di sekitar dusun tempat tinggalnya. Mayoritas peserta kegiatan tersebut adalah ibu rumah tangga dengan rentang umur produktif antara 30-40 tahun, dengan suami yang bermatapencaharian sebagai petani.

Kegiatan Pemberdayaan Pangan Lokal di kelompok tersebut masih dalam tahap rintisan, dengan terus mengadakan pertemuan sebulan sekali untuk melakukan penggalian potensi lokal dan pelatihan pembuatan produk olahan pangan lokal. Di setiap pertemuannya, anggota kelompok harus menyisihkan uang Rp 5.000,00 untuk arisan dan $\mathrm{Rp} 2.000,00$ untuk iuran kegiatan kelompok. Selain pertemuan dan pelatihan yang didampingi oleh PPL Kecamatan Tempel, kelompok ini juga aktif dalam mengikuti berbagai perlombaan olahan pangan lokal yang diadakan oleh Pemerintah di lingkup Desa, Kecamatan, Kabupaten, bahkan Propinsi, seperti BKPP (Badan Ketahan Pangan dan Penyuluhan) dan Dinas Pertanian.

\section{HASIL DAN PEMBAHASAN}

Pengarusutamaan Gender (PUG) merupakan salah satu strategi yang dilakukan oleh pemerintah Indonesia dalam rangka menindaklanjuti kebijakan terkait kesetaraan gender yang sedang menjadi perhatian khusus oleh Negara-negara di dunia. Pemerintah Indonesia melalui Instruksi Presiden Nomor 9 tahun 2000 mengartikan PUG merupakan strategi yang dibangun untuk mengintegrasikan gender menjadi satu dimensi integral dari perencanaan, penyusunan, pelaksanaan, pemantauan, dan evaluasi atas kebijakan dan program pembangunan nasional.

Atas dasar pengertian tersebut berarti bahwa segala kegiatan pembangunan yang dilakukan haruslah mendasarkan atas keadilan gender, baik dalam taraf lingkungan keluarga, masyarakat, birokrasi, bahkan rencana kebijakan dan melibatkan baik laki-laki maupun perempuan agar dapat memperoleh kesempatan dan hak-haknya sebagai manusia, termasuk dalam kaitannya dengan keterlibatan perempuan di kegiatan publik. Implementasi kesetaraan gender dalam sebuah kebijakan dapat diketahui melalui analisa gender, yang dilakukan dengan mengidentifikasi dan memahami akses dan kontrol terhadap sumberdaya dan manfaat, partisipasi dalam kegiatan pembangunan, serta manfaat yang diperoleh dari kegiatan pembangunan, termasuk dalam kegiatan pemberdayaan pangan lokal di Desa Mororejo.

\section{Pembagian Kerja secara Gender dalam Program Pemberdayaan Pangan Lokal}

Program pemberdayaan pangan lokal di Kecamatan Tempel sudah berjalan 2 (dua) tahun, dan masih dalam tahap menelusuri potensi olahan pangan lokal sekitar dengan rutin mengadakan pelatihan pengolahan satu bulan sekali. Pertemuan rutin tersebut sekaligus dimanfaatkan oleh peserta untuk menggali informasi sebanyak-banyaknya mengenai pasar 
yang potensial, keberadaan modal, dan pengetahuan baru bagi perkembangan usaha mereka. Kegiatan pemberdayaan pangan lokal memang dirancang untuk memberdayakan ibu rumah tangga di Desa Mororejo yang memiliki keinginan untuk memiliki usaha rumahan dengan basis potensi lokal yang dimiliki di sekitar tempat tinggalnya. Namun, jika menilik INPRES No 9 Tahun 2009 tentang Pengarusutamaan Gender, yaitu melibatkan perempuan dalam kegiatan pembangunan berbasis gender, laki-laki dan perempuan seharusnya sama-sama memiliki kesadaran yang tinggi untuk terlibat dalam setiap rangkaian kegiatan program tersebut. Kenyataannya, kegiatan pemberdayaan pangan lokal di Desa Mororejo dilakukan sepenuhnya oleh perempuan. Kegiatan pemberdayaan pangan lokal di desa tersebut terdiridari beberapa aktivitas, yaitu pelatihan dan arisan yang diadakan rutin secara bersamaan sebulan sekali pada tanggal 12, lomba-lomba olahan pangan lokal yang dilakukan baik di tingkat padukuhan, desa, kecamatan, dan kabupaten, serta praktik olahan di rumah.

Kegiatan utama dalam pemberdayaan pangan lokal ini terletak pada pertemuan rutin yang dilakukan setiap bulan. Pada pertemuan tersebut, ibu rumah tangga pesertanya diberikan pelatihan mengenai olahan pangan lokal sesuai dengan kesepakatan menu yang sudah direncanakan pada pertemuan sebelumnya. Pada kesempatan pertemuan tersebut, pemerintah melalui kepala bagian pembangunan desa menyampaikan informasi yang menunjang kegiatan tersebut, seperti informasi lomba-lomba, keberadaan modal, pasar, dan sebagainya. Selain pihak desa, Petugas Penyuluh Lapangan (PPL) yang selalu memberikan materi pada kegiatan ini juga senantiasa memberikan semangat dan motivasi anggota kelompok untuk terus berinovasi, melakukan kreasi olahan pangan lokal yang menarik dan bernilai jual tinggi. Dalam pertemuan itu juga kelompok mengadakan arisan untuk lebih mengakrabkan anggota yang terdiri dari 13 padukuhan di Desa Mororejo.

Selain pertemuan rutin dan arisan, kegiatan lainnya yaitu lomba kreasi olahan pangan lokal baik yang diadakan di padukuhan, desa, kecamatan, maupun kabupaten. Lomba kreasi olahan ini memang rutin dilakukan, dan peserta kegiatan pemberdayaan pangan lokal di Desa Mororejo pasti mengikutinya. Perlombaan tersebut juga digunakan sebagai salah satu ajang bagi pemerintah dalam mendukung kegiatan pengembangan pangan lokal di daerah Sleman. Kegiatan lomba tersebut tidak dapat diprediksi pelaksanaannya, namun pasti dilakukan baik seminggu sekali maupun sebulan sekali. Dalam mempersiapkan perlombaan tersebut, ibu rumah tangga peserta kegiatan pemberdayaan pangan lokal di Desa Mororejo berusaha sendiri secara individu sejak menentukan menu hingga menyajikan. Suaminya hanya mengantar belanja dan jika ada waktu dan perempuan kerepotan untuk membawa sajian olahan pangan lokal, mereka juga mengantarkan ke lokasi lomba. Selain itu, mereka juga akan melakukan kegiatan bila memerlukan ketela dalam pengolahannya, karena mereka akan melakukan kegiatan tersebut untuk pasangannya. Kedua kegiatan tersebut dilakukan di sela-sela aktivitas laki-laki dalam mencari nafkah, atau jika kegiatan perlombaan dilakukan pada akhir pekan.

Selain kegiatan pertemuan rutin, arisan, dan perlombaan, peserta kegiatan pemberdayaan pangan lokal juga mempraktekkan hasil pelatihan olahan dalam kegiatan pertemuan di rumah masing-masing, dan terkadang memproduksi dalam jumlah banyak untuk dipasarkan. Dalam kegiatan praktek tersebut, partisipasi laki-laki di dalamanya masih sama dengan kegiatan lainnya, sebatas kegiatan yang membutuhkan tenaga lebih banyak seperti mencabut ketela dan mengantar belanja atau ke pasar jika bawaan 
terlalu banyak dan perempuan kerepotan untuk membawanya.

Berdasarkan uraian tersebut, maka pembagian kerja secara gender dalam rangka terlibat dalam rangkaian kegiatan pemberdayaan pangan lokal di Desa Mororejo ditunjukkan oleh hasil pada Tabel 1. Tabel tersebut menunjukkan bahwa perempuan mendominasi setiap tahapan aktivitas terkait program pemberdayaan pangan lokal dengan total 16 pekerjaan, namun laki-laki juga turut berpartisipasi dalam total 8 pekerjaan. Aktivitas yang dilakukan laki-laki terbatas hanya pada pekerjaan yang menggunakan tenaga berlebih, seperti mencabut ketela sebagai salah satu bahan baku yang digunakan untuk membuat pangan lokal, dan pekerjaan terkait dengan kegiatan di luar rumah, seperti mengantar istrinya belanja bahan lain yang dibutuhkan untuk proses produksi di pasar dan mengantarkan hasil

Tabel 1 Pembagian Kerja secara Gender dalam Program Pemberdayaan Pangan Lokal

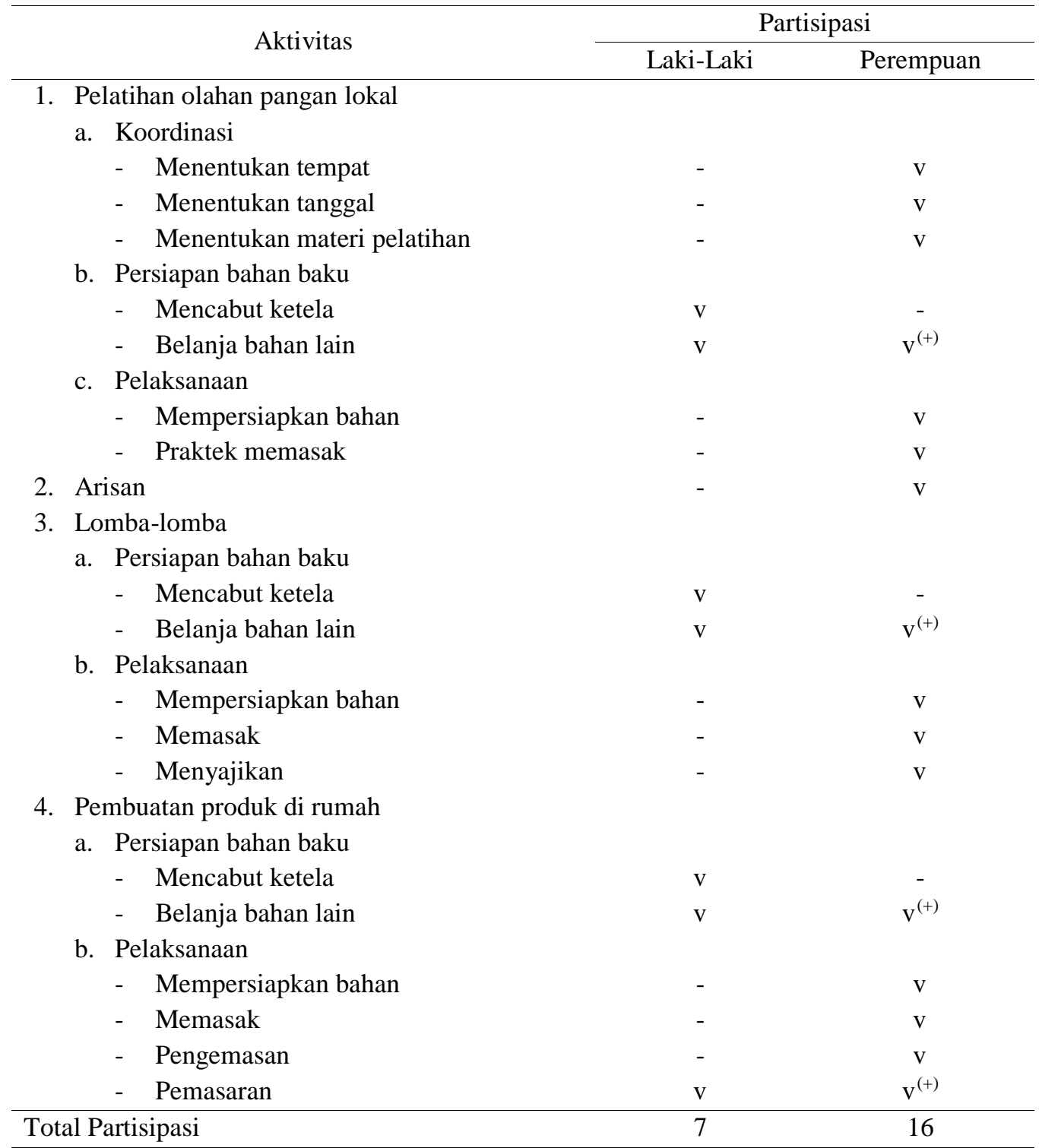

Keterangan: ${ }^{(+)}$Dominan dalam mengerjakan

Sumber : Data Primer, 2016 
produksi ke pasar atau toko-toko langganannya untuk dipasarkan.

Keterlibatan laki-laki pada pekerjaan yang menggunakan tenaga saja menunjukkan masih ada perbedaan yang sangat tegas antara pekerjaan laki-laki dan perempuan dalam program tersebut. Dalam hal belanja bahan pelengkap lainnya, laki-laki biasanya mengantar pasangannya ke pasar, namun ada beberapa anggota yang melakukannya sendiri karena laki-laki dalam keluarganya harus ke sawah, atau melakukan pekerjaan lainnya. Hal yang sama juga terjadi dalam partisipasinya untuk kegiatan pemasaran, jika dirasa sulit untuk membawa produk sendiri.

Berdasarkan uraian hasil dari Tabel 1, perbedaan peran antara laki-laki dan perempuan dalam program pemberdayaan pangan lokal yang paling mencolok terletak pada keterlibatan laki-laki yang masih sangat minim. Mereka hanya melakukan kegiatan berat yang menurut mereka memerlukan tenaga berlebih, dan perempuan dianggap tidak mampu melakukannya sendiri, atau pekerjaan yang secara emosional menunjukkan perhatian dengan pasangan, seperti mengantar dan menemani. Mereka juga tidak berpartisipasi pada kegiatan pengolahan dan proses produksi karena bagi mereka pekerjaan memasak yang berkaitan dengan kompor serta kreasi dapur merupakan pekerjaan perempuan, dan banyak diantara mereka yang tidak ingin melakukan hal tersebut karena kebiasaan memasak di rumahnya dilakukan oleh perempuan.

Berdasarkan dominasi pekerjaan antara laki-laki dan perempuan dalam rumah tangga yang tersaji dalam Tabel 1 tersebut, terjadi pembagian peran gender dalam rumah tangga yang masih tradisional. Hasil penelitian Nurlian dan Daulay (2008) tidak sepenuhnya benar pada masyarakat di Desa Mororejo, karena pembagian tersebut tidak terlalu tegas dengan meminggirkan nasib kaum perempuan dengan dominasi dapurnya.
Hal tersebut dibuktikan dengan keterlibatan perempuan dalam kegiatan publik terkait dengan kegiatan pemberdayaan pangan lokal di desanya. Hasil dari pembagian kerja tersebut juga membuktikan bahwa meskipun masih melekat erat budaya patriarki di dalamnya, masyarakat di Desa Mororejo mulai meninggalkan Traditional GRA, dan sedang dalam peralihan untuk memulai ideologi Egalitarian GRA.

Traditional Gender Role Attitude (Traditional $G R A$ ) merupakan stereotip tradisional mengenai pembagian kerja dalam rumah tangga, yang mengungkapkan bahwa hal-hal yang dilakukan laki-laki, tidak dilakukan oleh perempuan dan begitu pula sebaliknya (Orlofsky, 1982). Egalitarian Gender Role Attitude (Egalitarian GRA) merupakan lawan dari Traditional GRA, yang menganut fleksibilitas dalam pembagian kerja (Felton et al. 1980). GRO yang dianut oleh laki-laki dan perempuan dalam rumah tangga Egalitarian GRA adalah androgini (Orlofsky, 1982), yaitu semua bisa dilakukan baik oleh lakilaki dan perempuan, dan sharing pekerjaan diantara keduanya dalam rumah tangga pun terjadi secara lebih fleksibel. Peralihan ideologi tradisional GRA menuju egalitarian GRA nampak pada komunikasi yang terjalin antara laki-laki dan perempuan di Desa Mororejo, sharing pekerjaan, dan kesepakatan-kesepakatan terkait pembagian kerja diantara pasangan lakilaki dan perempuan dalam rumah tangga, yakni suami dan istri.

Dengan demikian, kegiatan pemberdayaan pangan lokal di Desa Mororejo memang diperuntukkan bagi kaum ibu rumah tangga di desa tersebut, sehingga laki-laki merasa tidak perlu mencampurinya pada kegiatan kelompok. Namun, kepahaman laki-laki sebagai suami dalam mendukung istrinya untuk mensukseskan kegiatan tersebut ada pada dukungan dengan mengantar belanja, terkadang mengantar ke pertemuan, memotivasi untuk menjual hasil 
olahannya, dan bahkan sampai mencarikan pasar untuk menitipkan hasil olahan tersebut, karena laki-laki lebih banyak memiliki jaringan komunikasi yang luas dengan keterlibatannya dalam dunia publik. Kepahaman tersebut menunjukkan keberadaan gender relations atau hubungan gender antara laki-laki dan perempuan di Desa Mororejo telah terjalin dengan baik.

\section{KESIMPULAN}

Partisipasi masyarakat dalam kegiatan pemberdayaan pangan lokal di Desa Mororejo sangat tinggi, utamanya yaitu ibu-ibu rumah tangga yang merupakan sasaran utama kegiatan tersebut. Perempuan terlibat dalam setiap kegiatan, baik pada kegiatan pelatihan olahan pangan lokal, arisan, lomba-lomba, dan pembuatan produk di rumah. Sedangkan laki-laki hanya terlibat dalam kegiatan mengantar pasangannya belanja bahan lain, mencabut ketela, dan mengantar untuk kegiatan pemasaran. Hal tersebut disebabkan karena peta awal pembentukan kelompok pemberdayaan ini dalam untuk memberdayakan perempuan, sehingga laki-laki merasa tidak perlu ikut campur terlalu dalam dan memberikan partisipasinya dalam bentuk dukungan untuk pasangannya.

\section{DAFTAR PUSTAKA}

2009. Instruksi Presiden Republik Indonesia Nomor 9 tahun 2009 tentang Pengarusutamaan Gender (PUG). . 2012. Undang-Undang Republik Indonesia Nomor 18 tahun 2012 tentang Pangan.
Cohen, J.M dan Uphoff, T. 1997. Rural Development Participation: Concept and Measures for Project Design, Implementation and Evaluation. Cornell University. New York.

Creswell, J.W. 2014. Research Design Pendekatan Kualitatif, Kuantitatif, dan Mixed. Pustaka Pelajar. Jakarta.

Felton, B.J., Lehmann, S., Brown, P., and Penny Liberatos. 1980. The coping function of sex-role attitude during marital disruption. Journal of Health and Social Behavior (21): 240-248.

March, C., Symth, I., Maitrayee M. 2010. A Guide to Gender-Analysis Framework. Oxfam Publication. London

Mosse, J.V, 2007. Gender dan Pembangunan. Pustaka Pelajar. Jakarta.

Nugroho, R., 2008. Gender dan Strategi Pengarusutamaannya di Indonesia. Pustaka Pelajar. Yogyakarta.

Nurlian dan Daulay, H. 2008. Kesetaraan gender dalam pembagian kerja pada keluarga petani ladang: Studi kasus analisa isu gender pada keluarga petani ladang di Kecamatan Kuala Kabupaten ngan Raya NAD. Jurnal Harmoni Sosial Vol. 2.

Orlofsky, J.L. 1982. Psychological androgyny, sex typing, and sex-role ideology as predictors of male-female interpersonal attraction. Jurnal Sex Role vol. 8 No. 10.

Schiller, B.M. 1978. Work, and Status in Rural Java. Ohio University. 